\title{
MENINGKATKAN HASIL BELAJAR BOLA VOLI MELALUI MODIFIKASI PERMAINAN BOLA VOLI MINI SISWA KELAS VI SDN 020 RAMBAH HILIR KABUPATEN ROKAN HULU TAHUN PELAJARAN 2018/2019
}

\author{
ASRI \\ Guru Sekolah Dasar Negeri SDN 020 Rambah Hilir
}

\begin{abstract}
ABSTRAK
Pembelajaran penjas orkes yang sering kali tidak sesuai dengan karateristik siswa membuat kreativitas anak menjadi terabaikan dan hasil pembelajaran menjadi kurang maksimal. Maka perlu adanya modifikasi media pembelajaran yang sesungguhnya. Permasalahan pembelajaran menggunakan modifikasi bola voli mini dapat meningkatkan hasil belajar bola voli pada siswa kelas VI SDN 020 Rambah Hilir Kabupaten Rokan HuluTahun Pelajaran 2018/2019?” Tujuan penelitian ini untuk mengetahui meningkatnya hasil belajar bola voli melalui modifikasi bola voli mini. Penelitian ini dilaksanakan di VI SDN 020 Rambah hilir Kabupaten Rokan Hulu Tahun Pelajaran 2018/2019, sampel dalam penelitian ini adalah siswa kelas VI yang berjumlah 24 siswa. Penelitian ini merupakan penelitian tindakan kelas yang terdiri dari dua siklus dimana setiap siklus terdiri dari 4 tahap yaitu perencanaan, tindakan, observasi (pengamatan), dan refleksi.Teknik pengumpulan data dalam penelitian ini menggunakan lembar observasi serta angket/kuesioner yang digunakan untuk mengetahui pemahaman siswa terhadap materi sepak bola. Data hasil pengamatan siklus I dan II yaitu: unjuk kerja (psikomotor) diperoleh hasil sebesar 56,58\% dan 77,21\% dengan kriteria baik. Data hasil pengamatan sikap dan perilaku (afektif) adalah 63,67\% dan 78,04\% dengan kriteria baik. Data hasil penilaian pemahaman siswa (kognitif) sebesar 54,17\% dan 95,83\% dengan kriteria sangat baik. Berdasarkan perbandingan hasil yang dicapai antara siklus I dan siklus II, secara keseluruhan nilai yang diperoleh untuk setiap aspek terdapat peningkatan. Berdasarkan dari hasil penelitian diatas, disumpilkan bahwa pembelajaran dengan menggunakan modifikasi bola voli mini dapat meningkatkan hasil belajar bola voli siswa. Oleh karena itu diharapkan bagi siswa dengan adanya modifikasi permainan bola voli mini agar lebih semangat lagi mengikuti pembelajaran penjasorkes, bagi guru penjasorkes di VI SDN 020 Rambah hilir Kabupaten Rokan Hulu Tahun Pelajaran 2018/2019 dapat menggunakan modifikasi bola voli mini dalam pembelajaran bola voli, menggunakan modifikasi permainan bola voli mini sebagai alternatif pembelajaran penjasorkes, senagai sekolah juga diharapkan untuk meningkatkan sarana dan prasarana yang ada sebagai penunjang dalam pembelajaran penjasorkes.
\end{abstract}

Kata kunci : hasil belajar, modifikasi, bola voli mini,

\section{PENDAHULUAN}

Pendidikan Jasmani sebagai komponen pendidikan secara keseluruhan telah disadari oleh banyak kalangan. Namun dalam pelaksanaannya pengajar pendidikan jasmani berjalan belum efektif seperti yang diharapkan. Pembelajaran pendidikan jasmani cenderung tradisional. Model pembelajaran pendidikan jasmani tidak harus terpusat pada guru, tetapi pada siswa. Orientasi pembelajaran harus disesuaikan, dengan perkembangan anak, isi dan urusan materi serta cara penyampaian harus disesuaikan sehingga menarik dan menyenangkan, sasaran pembelajaran ditujukan bukan hanya mengembangkan keterampilan olahraga, tetapi pada perkembangan pribadi anak seutuhnya. Konsep dasar pendidikan jasmani dan model pengajar pendidikan jasmani yang efektif perlu dipahami oleh mereka yang hendak mengajar pendidikan jasmani.
Pengertian pendidikan jasmani sering dikaburkan dengan konsep lain. Pengertian pendidikan jasmani sering disamakan dengan setiap usaha atau kegiatan yang mengarah pada pengembangan organ-organ tubuh manusia (body building), kesegaran jasmani (physical fitness), kegiatan fisik (physical actVIities), dan pengembangan keterampilan (skill development). Pengertian itu memberikan pandangan yang sempit dan menyesatkan arti pendidikan jasmani yang sebenarnya. Walaupun memang benar aktVIitas fisik itu mempunyai tujuan tertentu, namun karena tidak dikaitkan dengan tujuan pendidikan, maka kegiatan itu tidak mengandung unsur-unsur pedagogik.

Pendidikan jasmani bukan hanya merupakan aktVIitas pengembangan fisik secara terisolasi, akan tetapi harus berada dalam konteks pendidikan secara umum (general education). Sudah tentu proses tersebut 
dilakukan dengan sadar dan melibatkan interaksi sistematik antarpelakunya untuk mencapai tujuan yang telah di tetapkan.

Penyelenggaraan program pendidikan jasmani olahraga dan kesehatan hendaknya mencerminkan karakteristik program pendidikan jasmani itu sendiri. Yaitu,"developmental appropriate“(DAP). Artinya tugas belajar yang diberikan harus memperhatikan perubahan kemampuan anak dan dapat membantu mendorong perubahan tersebut. Dengan demikian tugas ajar tersebut harus sesuai dengan tingkat perkembangan anak didik yang sedang belajar. Tugas ajar yang sesuai ini harus mampu mengakomodasi setiap perubahan yang lebih baik (Suherman,2000:1)

Pengertian pendidikan jasmani menurut para ahli. Pendidikan jasmani adalah bagian dari pendidikan nasional, artinya pendidikan jasmani tidak terfokus pada aspek motoriknya saja, tetapi juga terdapat aspek kognitif dan afektif. Pendidikan jasmani adalah pendidikan melalui aktVIitas yang dijadikan sebagai media untuk mencapai perkembangan indVIidu secara menyeluruh. Pendidikan jasmani adalah suatu proses pendidikan seseorang sebagai perorangan atau anggota masyarakat yang dilakukan secara sadar dan sistematik melalui berbagai kegiatan jasmani untuk memperoleh pertumbuhan jasmani, kesehatan dan kesegaran jasmani, kemampuan dan keterampilan, kecerdasan dan perkembangan watak serta kepribadian yang harmonis dalam rangka pembentukan manusia Indonesia berkualitas berdasarkan Pancasila. (Cholik Mutohir, 1992).

Jadi dapat disimpulkan, bahwa pendidikan jasmani merupakan proses pendidikan yang memanfaatkan aktVIitas jasmani dan direncanakan secara sistematik bertujuan untuk meningkatkan aspek kognitif, afektif, psikomotorik serta fisik.

Pada hakekatnya, pembelajaran pendidikan jasmani olahraga dan kesehatan di sekolah-sekolah umumnya disampaikan dalam bentuk permainan dan olahraga. Materi dan isi pembelajaran hendaknya diberikan secara bertahap sehingga tujuan pokok pembelajaran dapat dicapai oleh peserta didik. Untuk itu para guru seharusnya memiliki rencana pembelajaran yang didalamnya berisi bekal pengetahuan dan ketrampilan tentang setrategi dan struktur mengajar untuk peningkatan belajar anak.

Kenyataan di lapangan pendidikan jasmani yang ada saat ini belum dikelola sebagaimana mestinya, sesuai dengan tingkat pertumbuhan dan perkembangan peserta didik, baik dari segi kognitif, motorik, afektif dan fisik. Model pembelajaran yang tidak sesuai karakteristik anak, tidak ada kreatVIitas akan membuat anak merasa bosan, sehingga anak tidak bergairah untuk melakukan pembelajaran. Sebagai contoh pada pembelajaran voli. Pembelajaran seringkali tidak sesuai karakteristik anak, sehingga kreatVIitas kesenangan anak tidak terfikirkan. Hal tersebut membuat pembelajaran yang kurang maksimal sehingga hasil pembelajarannya juga kurang maksimal.

Maka seorang guru diharapkan bisa memodifikasi dari pembelajaran yang ada agar anak tidak cepat bosan, sehingga anak bergairah dan dapat termotVIasi untuk mengikuti pembelajaran selanjutnya. Ini adalah bukti nilai kegagalan pada pembelajaran tanpa menggunakan permainan modifikasi. Pada aspek afektif siswa tergolong dari kategori tuntas adalah sebanyak 2 siswa atau $8,33 \%$ dengan jumlah 24 siswa. Sedangkan pada aspek kognitif adalah sebanyak 1 siswa masuk dalam kriteria tuntas atau $4,17 \%$. Untuk aspek psikomotor sendiri mencapai 2 siswa mencapai kriteria tuntas atau 8,33\%.

Modifikasi merupakan salah satu usaha yang harus dilakukan oleh para guru agar pembelajaran mencerminkan DAP. Untuk itu DAP yang didalamnya memperhatikan ukuran tubuh siswa harus selalu menjadi prinsip utama dalam memodifikasi pembelajaran pendidikan olahraga dan kesehatan. Inti dari modifikasi adalah menganalisa dan mengembangkan materi pelajaran dengan cara meruntunkannya dalam bentuk aktVIitas belajar potensial yang dapat memperlancar siswa dalam belajarnya. (Suherman,2000: 1)

Pengembangan

pembelajaran permainan bola voli pada pendidikan jasmani melalui modifikasi sangatlah tepat dilakukan, karena selain variasi mengajarnya banyak, penyesuaian terhadap kemampuan anak sehingga mereka tidaklah terlalu bosan mengikuti pembelajaran, termotVIasi dan 
bergairah untuk bergerak. Proses pendidikan jasmani olahraga dan kesehatan siswa kelas VI SDN 020 Rambah Hilir kondisinya kurang sesuai karakteristik anak, permainan-permainan kecil yang mengundang tawa dan perasaan senang yang menjadi karakteristik anak masih belum digali secara maksimal, sehingga anak kurang aktif, cenderung membosankan, strategi pembelajaran yang dilakukan juga masih senantiasa menggunakan pendekatan drill atau perlakuan terus menurus layaknya pelatihan yang digunakan untuk mencetak seorang atlet, hal itu kurang tepat untuk dilakukan pada pembelajaran penjasorkes untuk siswa sekolah menengah karena tidak mengedepankan proses pada pembelajaran penjasorkes, dan oleh sebab itu pembelajaran permainan bola voli perlu dilakukan modifikasi dan juga perubahan dalam strategi pembelajaran.

\section{Landasan Teori}

\section{KAJIAN PUSTAKA}

\section{Pendidikan Jasmani Olahraga dan Kesehatan}

Pendidikan jasmani adalah pendidikan melalui jasmani, jasmani adalah kata sifat dengan asal kata jasat yang berarti tubuh atau badan. Dengan pandangan ini maka jasmani berkaitan dengan perasaan, hubungan pribadi, tingkahlaku kelompok, perkembangan mental dan sosial, intelektual serta estetika.

Pendidikan jasmani dilakukan dengan sarana jasmani, yakni aktVlitas jasmani yang pada umumnya dilakukan pada tempo yang cukup tinggi dan terutama gerakan-gerakan besar ketangkasan dan keterampilan, yang tidak perlu terlalu tepat, terlalu halus dan sempurna atau berkualitas tinggi. Agar diperoleh manfaat bagi anak-anak didik mencakup bidang-bidang non fisik seperti intelektual. Sosial, estetika, dalam kawasan-kawasan kognitif maupun afektif. (H. abdul kadir. 1992:4)

Pengertian pendidikan jasmani olahraga kesehatan adalah proses pendidikan keseluruhan yang mengacu pada aspek kognitif, afektif, psikomotorik, dan fisik yang terangkum dalam kurikulum pendidikan, bertujuan untuk meningkatkan kemampuan jasmani, mental, emosional dan sosial, serta menjadikan manusia yang seutuhnya sehat jasmani dan rohani untuk meningkatkan kebugaran jasmani.

\section{Permainan}

Bermain adalah melakukan sesuatu untuk bersenang-senang dan permainan adalah bermain (Poewadarminta, 2003:689) Telah diakui kebenarannya bahwa hidup manusia sejak dari kecil tumbuh dengan melewati beberapa macam bentuk pengalaman bermain. Dari mempelajari perkembangan indVIidu manusia beserta sejarahnya, dapat ditarik kesimpulan bahwa permainan itu ada. Oleh karena itu manusia tumbuh tidak dapat mengelakkan alam permainan. Anak-anak berkembang melewati bermacam-macam permainan sebagai kodrat yang alami (Soemitro 1992:3)

\section{a. Permainan Bola Voli Mini}

Permainan bola voli adalah memasukan bola kedaerah lawan melewati suatu rintangan berupa tali atau net dan berusaha memenangkan permainan bola itu di daerah lawan. Memvoli artinya memainkan atau memantulkan bola sebelum jatuh atau sebelum menyentuh lantai. (M. Yunus 1992 : 1)

Dalam hal ini permainan bola voli mini menggunakan tinggi net 2,00 meter dan besar lapangan $12,00 \times 6,00$ meter. Permainan bola voli mini merupakan salah satu permainan atau cabang olah raga yang ada dalam pembelajaran penjasorkes.

b. Teknik dasar bola voli mini :

Teknik dasar bola voli mini terdiri dari :

1) Servis, 2) Passing, 3) Smash (spike). 4) Bendungan (block)

1) Servis

Pada umumnya servis hanya merupakan pukulan pembukaan untuk memulai suatu permainan sesuai dengan kemajuan permainan, teknik servis ini hanya sebagai permulaan permainan, tetapi jika di tinjau dari sudut taktik sudah merupakan serangan awal untuk mendapat nilai agar suatu regu meraih kemenangan. Adapun macam-macam teknik servis dan variasinya sebagai berikut:

a) Servis tangan bawah ( Underhand service )

b) Servis mengapung ( Floating service )

c) Floating overhand serve

d) Overhand Change-Up service ( Slider Floating Overhand ) 
e) Overhand Round-hause (Hook Service)

f) Jumping service ( servis dengan melompat )

2) Passing

Passing adalah mengoperkan bola kepada teman sendiri kepada satu regu dengan suatu teknik tertentu, sebagai langkah awal untuk menyusun pola serangan kepada regu lawan. Adapun macammacam passing sebagai berikut :

a) Passing bawah normal

b) Variasi passing bawah

c) Passing atas normal

d) Variasi passing atas

e) Passing dalam berbagai ketinggian bola

f) Umpan ( Set Up )

Umpan adalah menyajikan bola kepada teman dalam satu regu, yang kemudian diharapkan bola tersebut dapat diserangkan kedaerah lawan dalam bentuk smash. Adapun macam-macam umpan sebagai berikut :

1) Menurut macam-macamnya smash : (1)

Umpan normal, (2) Umpan semi,

Umpan push ( umpan dorong ),

Umpan pull ( quick)

2) Menurut arah bola dari posisi pengumpan

: (1) Mengumpan kedepan dekat dan sejajar dengan net, (2) Mengumpan kebelakang dekat dan sejajar dengan net, (3) Umpan kedepan dengan meloncat, (4) Umpan kedepan dengan meloncat

3) Smash ( spike )

Smash adalah pukulan yang utama dalam penyerangan dalam usaha mencapai kemenangan. Untuk mencapai keberhasilan yang gemilang dalam melakukan smash ini diperlukan raihan yang tinggi dan kemampuan meloncat yang tinggi. Adapun macam-macam smash sebagai berikut :

a) Smash normal ( open smash )

b) Smash semi

c) Smash semi jalan

d) Smash push

e) Smash pull (quick)

f) Smash pull jalan

g) Smash pull straights

h) Smash cekis (drVIe smash)

i) Smash langsung

j) Smash dari belakang
4) Bendungan ( block )

Block merupakan benteng pertahanan yang utama untuk menangkis serangan lawan. Jika ditinjau dari teknik gerakan, block bukanlah teknik yang sulit. Namun keberhasilan suatu block prosentasenya relatif kecil karena bola smash yang akan dibolck, arahnya dikendalikan oleh lawan (lawan selalu menghindari block tersebut)

\section{A. Subyek Penelitian}

\section{METODE PENELITIAN}

Subjek penelitian ini adalah meningkatkan hasil belajar bola voli mini dengan bola plastik berlapis spon, net, lapangan, dan peraturan yang sudah disederhanakan pada siswa kelas VI SDN 020 Rambah Hilir sebanyak 24 siswa.

\section{B. Obyek Penelitian}

Obyek penelitian adalah keseluruhan subyek penelitian (Suharsimi Arikunto, 2006: 130). Yang menjadi populasi dalam penelitian ini adalah siswa kelas VI SDN 020 Rambah Hilir sebanyak 24 siswa.

\section{Desain Penelitian}

Penelitian tindakan kelas merupakan kegiatan mencermati objek penelitian yang mengorganisasi suatu kondisi, sehingga peneliti dapat mempelajari pengalaman tersebut, penelitian tindakan kelas (PTK) merupakan suatu pencermatan terhadap suatu kegiatan yang sengaja dimunculkan, dan terjadi dalam sebuah kelas. PTK terdiri dari empat tahapan yaitu rencana /perencanaan, tindakan, observasi, reflektif (Sukardi, 2008: 212). Tahapan PTK dapat digambarkan dengan bagan berikut ini:

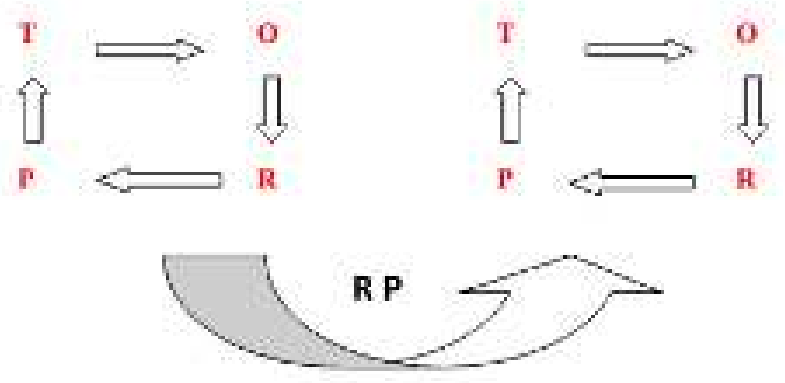

Keterangan:

$\mathrm{P} \quad$ : perencanaan

$\mathrm{T}$ : Tindakan

$\mathrm{O}$ : Observasi

$\mathrm{R}$ : Reflektif

RP : Revisi Perencanaan 
1. Siklus I

Siklus ini terdiri atas empat tahap yang meliputi perencanaan, tindakan,observasi, dan refleksi.

a. Perencanaan

Dalam tahap ini peneliti mempersiapkan proses pembelajaran yang menunjuk pada aspek-aspek yang perlu diamati yaitu aspek kognitif, afektif, dan psikomotorik. Selain itu peneliti juga harus memperispkan langkahlangkah yang akan dilakukan dalam penelitian diantaranya menyusun pedoman instrumen dan mempersiapkan Rencana Pelaksanaan Pembelajaran (RPP).

b. Tindakan

Pada tahap ini peneliti melakukan berbagai tidakan yang akan dilakukan dala proses penelitian yang sudah direncanakan. Materi pembelajarannya adalah menerangkan teknik dasar dan peraturan bermain modifikasi bola voli dengan penerapan permainan bola voli mini.

Pada tahap awal siswa ditanya tentang pengertian teknik dasar permainan bola voli, dan mencontohkannya. Dari kegiatan tersebut peneliti dapat melihat kelemahan dan keunggulan siswa dalam hal teknik dasar dan kecakapan geraknya. Selanjutnya siswa diberi pertanyaan-pertanyaan tentang peraturan bola voli. Melalui kegiatan ini peneliti dapat mengetahui sejauh mana pengetahuan siswa tantang permainan bola voli.

Pada tahap berikutnya peneliti memberi pengertian tentang penerapan permainan bola voli mini dan pertauran yang ada dalam modifikasi peraturan maupun lapangan yang ada dalam permainan bola voli mini.

c. Observasi

Observasi dilakukan secara cermat, tepat, dan rinci terhadap seluruh aktifitas siswa. Pada tahap ini peneliti memberikan waktu kepada siswa untuk bermain bola voli mini dengan menerapkan aturan permainan bola voli mini yang telah disepakati oleh peneliti dan kolaborator kemudian peneliti mencatat aktifitas serta kejadian selama proses tersebut berlangsung. Peneliti menggunakan lembar observasi yaitu berupa checklist. Checklist ini berisi indikator dari ketiga aspek yaitu kognitif, afektif, dan psikomotorik.

$$
\text { d. Refleksi }
$$

Pada tahap refleksi peneliti melakukan perincian kegiatan siswa yang telah dilakukan dalam proses belajar mengajar yang telah berlangsung. Data-data tersebut diteliti, dicermati, dilihat kekurangan dan kelebihan dari setiap kognitif, afektif dan psikomotornya. Kemudian kelemahan dalam proses belajar mengajar yang telah dilakukan dijadikan koreksi dalam siklus selanjutnya. Sedangkan kelebihannya dirangkum dijadikan pengetahuan dan pedoman dalam siklus berikutnya.

\section{Siklus II}

Siklus ini terdiri dari empat tahap yatu perencanaan, tindakan, observasi, dan refleksi.

a. Perencanaan

Pada tahap ini peneliti melakukan perbaikan dari siklus I dengan menyusun Rencana Pelaksanaan Pembelajaran (RPP) dan membuat pedoman pembelajaran.

b. Tindakan

Tidnakan yang dilakukan pada siklus II merupakan perbaikan dari langkah-langkah yang dilakukan pada siklus I. Pada tahap ini peneliti lebih detil dalam menerangkan materi penerapan permainan bola voli mini. Peneliti menerangkan peraturan permainan, ukuran lapangan, dan tinggi net yang diperlukan dalam permainan bola voli mini. Salah satu siswa ditunjuk oleh peneliti untuk mempraktikkan teknik dasar. Apabila ada kesalahan dan kekurangan dapat dibenarkan oleh peneliti dengan memberikan contoh yang baik dan benar. Selain memberikan contoh dalam melakukan gerakan teknik dasar permainan bola voli peneliti juga membekali siswa dengan filosofi dalam permainan ini yaitu untuk bersikap sportif pada lawan main dan menerima kebijakan wasit, hal tersebut akan meningkatkan kedisiplinan siswa dan emmbangun karakter siswa agar bisa menjadi seorang yang sportif dan mau berusaha keras untuk mencapai impian.

c. Observasi

Pada tahap observasi siklus II peneliti menggunakan checklist yang sama dengan checklist pada siklus I yang mengandung aspek kognitif, afektif, dan psikomotor. Peneliti memberikan instruksi kepada siswa untuk melakukan game dan mencatat aktifitas siswa secara cermat, tepat dan akurat dengan menggunakan checklist. 
d. Reflektif

Tahap ini merupakan tahap terakhir pada siklus II. Hasil pengamatan diteliti dan dianalisis apakah terjadi peningkatan pencapaian pembelajaran penjasorkes oleh siswa dilihat dari aspek afektif, kognitif dan psikomotornya.

\section{Indikator Keberhasilan}

Indikator keberhasilan dalam penelitian ini dapat ditunjukkan dengan ketuntasan belajar siswa. Berdasarkan teori belajar tuntas, maka seorang pendidik dipandang tuntas belajar jika mampu menyelesaikan, menguasai kompetensi atau mencapai tujuan pembelajaran minimal $75 \%$ atau mendapat nilai 75 dari seluruh tujuan pembelajaran. Sedangkan keberhasilan kelas dilihat dari jumlah peserta didik yang mampu menyelesaikan atau mencapai minimal skor dapat dilihat pada
$85 \%$, Sekurang-kurangnya $85 \%$ dari jumlah peserta didik yang ada di kelas tersebut. (Mulyasa, 2005: 99).

\section{HASIL PENELITIAN DAN PEMBAHASAN}

Pada dasarnya dalam penelitian tindakan kelas perlu dilakukan serangkaian tahapan yang akan dapat memenuhi hasil yang diharapkan berdasarkan sikap, pemahaman, serta kompetensi bermain. Kegiatan penelitian ini diawali dari kegiatan perencanaan, pelaksanaan, observasi, dan refleksi. Masalah tersebut akan penulis jelaskan secara rinci sebagai berikut:

\section{Data Siklus I}

Dari pelaksanaan kegiatan pada siklus pertama diperoleh hasil dengan penjelasan sebagaimana di bawah ini (penilaian secara indVIidu

siswa

\section{lampiran-lampiran)}

Tabel 1. Rekapitulasi Penilaian Hasil Belajar Permainan Bola Voli Mini Per Aspek Penilaian Pada Siklus I

\begin{tabular}{|c|l|c|c|c|c|c|}
\hline \hline \multirow{2}{*}{ No } & \multirow{2}{*}{$\begin{array}{c}\text { Aspek } \\
\text { Penilaian }\end{array}$} & \multicolumn{5}{|c|}{ Nilai / Ketuntasan } \\
\cline { 3 - 7 } & Skor & Tuntas & \% & Belum & \% \\
\hline 1 & Afektif & 56,58 & 6 & 25,00 & 18 & 75,00 \\
\hline 2 & Kognitif & 54,17 & 13 & 54,17 & 11 & 45,83 \\
\hline 3 & Psikomotorik & 63,67 & 12 & 50,00 & 12 & 50,00 \\
\hline & & & & & & \\
\hline \hline
\end{tabular}

a. Obsevasi (Pengamatan)

Dari data hasil observasi dan catatan lapangan, kemudian diskusi dengan obsever lainnya sebagai mitra peneliti, ditemukan beberapa hal yang menjadi kendala pembelajaran pada siklus petama yaitu:

1) Penguasaan kemampuan bermain yang beragam dari karakteristik siswa, baik dalam segi teknik maupun taktik. Ada siswa yang dapat dikategorikan memiliki teknik bermain yang cukup bagus, akan tetapi ada juga siswa yang masih sangat asing dengan permainan bolavoli mini.

2) Siswa cenderung kurang memperhatikan apa yang sudah dijelaskan dan dicontohkan oleh guru.

3) Keragaman karakteristik siswa harus diperhatikan oleh guru dengan cara menjelaskan yang lebih singkat, jelas dan dimengerti pemahaman pola permainan bolavoli mini baik dari segi teknik maupun taktik. b. Refleksi

Dari hasil observasi dan diskusi dengan mitra peneliti didapat data yang dapat dijadikan sebagai bahan refleksi pembelajaran siklus pertama, yaitu sebagai berikut:

1) Berikan umpan balik (feed back), seperti pujian dan penghargaan dari apa yang sudah dilakukan oleh siswa.

2) Selalu memberikan kesempatan bergerak lebih banyak terhadap anak sehingga pengalaman belajar bisa meningkat seperti memanfaatkan jumlah bola untuk aktVIitas gerak yang dilakukan siswa.

3) Berikan penjelasan dan contoh yang baik supaya siswa lebih memahami materi yang sedang diajarkan.

4) Eksplorasi potensi siswa seperti bertanya kepada siswa tentang pemahaman bermain bolavoli mini.

5) Posisi guru lebih ditingkatkan dengan berkeliling supaya aktVIitas siswa dapat lebih terkontrol/terawasi. 
6) Berikan tindak lanjut kepada siswa terkait materi yang telah disampaikan.

\section{Data Siklus II}

Penjelasan mengenai hasil kegiatan pembelajaran pada siklus kedua sebagaimana dijelaskan pada tabel di bawah ini. (Penjelasan hasil penilaian per siswa dapat dilihat pada lampiran-lampiran)

Tabel 2. Rekapitulasi Penilaian Hasil Belajar Permainan Bola Voli Mini Per Aspek Penilaian pada Siklus II

\begin{tabular}{|c|l|c|c|c|c|c|}
\hline \hline \multirow{2}{*}{$\begin{array}{c}\text { N } \\
\text { o }\end{array}$} & $\begin{array}{c}\text { Aspek } \\
\text { Penilaian }\end{array}$ & \multicolumn{5}{|c|}{ Nilai / Ketuntasan } \\
\cline { 3 - 7 } & & $\begin{array}{c}\text { Tunt } \\
\text { as }\end{array}$ & \% & $\begin{array}{c}\text { Belu } \\
\text { m }\end{array}$ & \% \\
\hline & & 77, & & 91, & & 8,3 \\
1 & Afektif & 21 & 22 & 67 & 2 & 3 \\
\hline & & 95, & & 95, & & 4,1 \\
2 & Kognitif & 83 & 23 & 83 & 1 & 7 \\
\hline & Psikomot & 78, & & 91, & & 8,3 \\
3 & orik & 04 & 22 & 67 & 2 & 3 \\
\hline \hline
\end{tabular}

\section{a. Observasi Pengamatan}

Dari hasil observasi dan catatan lapangan, yang kemudian didiskusikan dengan observer sebagai mitra peneliti, ditemukan beberapa hal mengenai pembelajaran pada siklus II ini, yaitu:

1) Siswa mulai bisa memahami tentang materi permainan bolavoli mini.

2) Kemampuan bermain yang dilakukan siswa mulai terlihat adanya peningkatan kususya terhadap siswa laki-laki.

3) Dengan penambahan suasana kompetisi membuat pembelajaran lebih bergairah.

\section{b. Refleksi}

Dari hasil observasi dan diskusi dengan mitra peneliti dapat dijadikan bahan untuk refleksi pembelajaran, yaitu:

1) AktVIitas siswa dari segi afektif, kognitif, dan psikomotor meunjukkan arah yang lebih baik.

2) Bermain adalah dunia anak, pembelajaran melalui pendekatan bermain bisa meningkatkan ranah sikap, pengetahuan materi dan keterampilan gerak siswa.

\section{B. Pembahasan}

\section{Aspek Perilaku Sikap (Afektif)}

Pada aspek afektif ini, yang diamati adalah sikap dan perilaku siswa selama mengikuti pembelajaran. Saat pembelajaran berlangsung, peneliti mengamati tingkah laku yang dilakukan sati per satu siswa secara bergantian. Sebagian besar siswa sudah menunjukkan perilaku yang baik selama proses pembelajaran. Misalnya, siswa sudah datang tepat waktu saat pembelajaran, memperhatikan setiap instruksi dan perintah yang diberikan guru, menghargai sesama teman, dan sebagainya.

Hasil pengamatan afektif siswa selama proses pembelajaran bolavoli mini pada siklus I dan II dapat dilihat pada tabel berikut:

Tabel 3. Rekapitulasi Hasil Pengamatan Perilaku Siswa Aspek Afektif pada Siklus I dan Siklus II

\begin{tabular}{|c|c|c|c|}
\hline No & $\begin{array}{c}\text { Aspek } \\
\text { Penilaan }\end{array}$ & $\begin{array}{c}\text { Siklus } \\
\text { I }\end{array}$ & $\begin{array}{c}\text { Siklus } \\
\text { II }\end{array}$ \\
\hline 1 & Afektif & 56,58 & 77,21 \\
\hline
\end{tabular}

Perbandingan hasil pengamatan afektif siswa pada masing-masing siklus ditunjukkan pada gambar berikut.

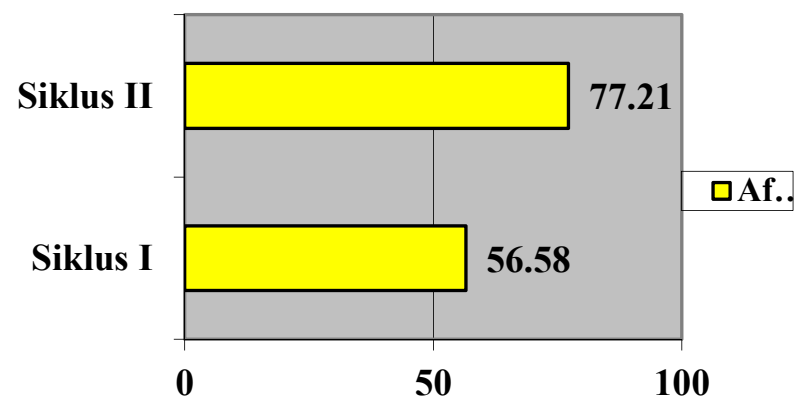

\section{Gambar 1. Perbandingan}

Pengamatan Afektif Siswa pada Siklus I dan Siklus II

Melihat dari hasil pengamatan perilaku siswa pada siklus I, persentase rata-rata siswa mencapai $56,58 \%$ yang dinyatakan dengan kriteria cukup baik, ini menunjukkan siswa sudah mengerti terhadap tujuan pembelajaran yang ingin dicapai. Dengan demikian, pada siklus II perlu dipertahankan dari apa yang sudah diterapkan oleh siswa, akan tetapi guru harus tetap selalu memberikan motVIasi yang dapat mendorong siswa lebih berkompetensi secara sportif. Hal ini yang mengharuskan peneliti untuk melanjutkannya pada siklus II. 
Setelah dilakukan pembelajaran pada siklus II dengan materi yang sama yaitu Bolavoli mini, persentase rata-rata siswa mencapai $77,21 \%$ yang juga dinyatakan baik. Hal ini menunjukkan bahwa siswa sudah paham terhadap tujuan pembelajaran yang dilaksanakan.

\section{Aspek Pemahaman Siswa (Kognitif)}

Untuk aspek kognitif ini, yang diamati adalah pengetahuan siswa tentang permainan bolavoli mini. Untuk mendapatkan data tentang pengetahuan siswa, peneliti memberikan lembar kuesioner kepada setiap siswa yang berisi soalsoal tentang permainan bolavoli mini. Kegiatan ini dilaksanakan setelah pelaksanaan permainan bolavoli mini, dialokasikan waktu 15 menit pada saat sesi evaluasi pembelajaran berlangsung. Sebagian besar siswa sudah mengetahui tentang pengetahuan dasar permainan bolavoli mini yang ada, misalnya berapa ukuran lapangan bolavoli mini, berapa jumlah pemain dalam sebuah tim, dan beberapa peraturan yang ada di dalam sebuah pertandingan bolavoli mini.

Hasil penilaian pemahaman siswa terhadap materi pembelajaran Bolavoli mini dapat dilihat pada tabel berikut:

Tabel 4. Hasil Pengamatan Pemahaman Kognitif Siswa pada Siklus I dan Siklus II

\begin{tabular}{|c|c|c|c|}
\hline No & $\begin{array}{c}\text { Aspek } \\
\text { Penilaan }\end{array}$ & $\begin{array}{c}\text { Siklus } \\
\text { I }\end{array}$ & $\begin{array}{c}\text { Siklus } \\
\text { II }\end{array}$ \\
\hline 1 & Kognitif & 54,17 & 95,83 \\
\hline
\end{tabular}

Perbandingan hasil penilaian pemahaman siswa (kognitif) pada masing-masing siklus ditunjukkan pada gambar berikut:

Siklus II

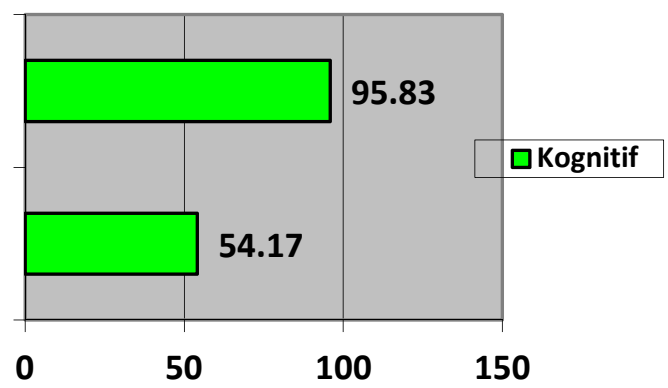

Gambar 2. Perbandingan Nilai Kognitif Siswa pada Siklus I dan Siklus

Melihat dari hasil penilaian terhadap pemahaman siswa pada siklus I, pengetahuan siswa terhadap modifikasi permainan bolavoli mini, persentase rata-rata siswa mencapai
$54,17 \%$ yang dinyatakan dengan kriteria baik. Hal ini menunjukkan pengetahuan siswa terhadap modifikasi permainan bolavoli mini sudah baik. Dengan demikian, pada siklus II perlu adanya motVIasi yang dapat mendorong siswa lebih giat lagi belajar supaya nilai yang sudah didapat bisa dipertahankan. Hal ini yang mendorong peneliti untuk melanjutkannya pada siklus II. Setelah dilakukan pembelajaran pada siklus II dengan materi yang sama yaitu Bolavoli mini persentase rata-rata siswa terhadap pembelajaran Bolavoli mini mencapai 95,83 \% yang juga dinyatakan dengan kriteria sangat baik, ini menunjukkan bahwa siswa sudah paham terhadap permainan Bolavoli mini.

\section{Aspek Unjuk Kerja (Psikomotor)}

Pada aspek psikomotor ini, yang diamati adalah unjuk kerja gerak siswa selama mengikuti pembelajaran. Saat pembelajaran berlangsung, peneliti mengamati setiap gerakan psikomotorik yang dilakukan oleh siswa.Sebagian besar siswa belum dapat melakukan teknik dasar permaina bolavoli mini dengan baik selama proses pembelajaran. Hal ini dikarenakan siswa masih merasa asing dengan teknik dasar bolavoli mini yang sesungguhnya. Namun siswa tetap merasa antusias untuk melakukan permainan bolavoli mini.

Data hasil pengamatan keterampilan psikomotor diperoleh hasil seperti pada tabel berikut:

Tabel 5. Hasil Pengamatan Keterampilan Psikomotorik Siswa pada Siswa pada Siklus I dan Siklus II

\begin{tabular}{|c|c|c|c|}
\hline No & $\begin{array}{c}\text { Aspek } \\
\text { Penilaan }\end{array}$ & $\begin{array}{c}\text { Siklus } \\
\text { I }\end{array}$ & $\begin{array}{c}\text { Siklus } \\
\text { II }\end{array}$ \\
\hline 1 & Psikomottor & 63,67 & 78,04 \\
\hline
\end{tabular}

Perbandingan hasil pengamatan keterampilan psikomotor siswa pada masing-masing siklus ditunjukkan pada gambar berikut :

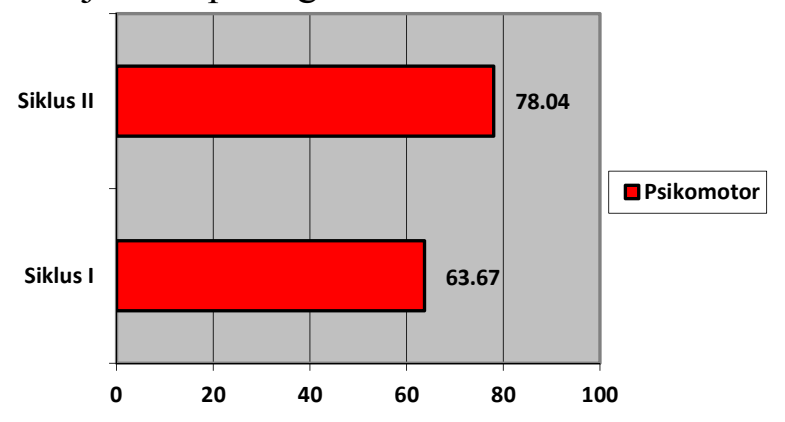


Gambar 3. Perbandingan Keterampilan Psikomotor pada Siklus I dan Siklus II

Melihat dari hasil pengamatan keterampilan psikomotor pada siklus I, teknik dasar siswa dalam bermain modifikasi permainan bolavoli mini persentase rata-rata siswa mencapai $63,67 \%$ yang dinyatakan dengan kriteria cukup. Hal ini menunjukkan bahwa siswa masih merasa kesulitan dan belum siap dalam memainkan modifikasi permainan Bolavoli mini. Dengan demikian, pada siklus II perlu adanya motVIasi yang dapat mendorong siswa lebih berkompetensi. Hal ini yang mendorong peneliti untuk melanjutkannya pada siklus II.

Setelah dilakukan pembelajaran pada siklus II dengan materi yang sama yaitu Bolavoli mini, persentase rata-rata siswa terhadap pembelajaran Bolavoli mini mencapai $78,04 \%$ yang juga dinyatakan cukup. Hal ini menunjukkan bahwa siswa sudah mendapatkan peningkatan dalam melaksanakan model pembelajaran modifikasi permainan Bolavoli mini walaupun dengan angka yang kecil. Dengan demikian terjadi peningkatan antara siklus I dan siklus II.

Hasil peningkatan yang tidak terlalu besar ini disebabkan beberapa faktor yang ada selama proses pembelajaran berlangsung. Hal tersebut antara lain karena sebelumnya siswa belum pernah atau masih asing dengan permainan Bolavoli mini, siswa kurang berlatih atau belajar secara mandiri, serta sebelumnya siswa belum mengetahui cara dan teknik yang benar dalam permainan Bolavoli mini.

\section{Antar Siklus}

Dari ketiga aspek pengamatan yang dilakukan, semua aspek menunjukkan peningkatan pada setiap siklusnya. Penjelasan mengenai peningkatan ke tiga aspek tersebut sebagaimana dijelaskan di bawah ini :

Tabel 6. Rekapitulas Hasil Pengamatan Keterampilan Afektf, Kognitif dan Psikomotorik Siswa pada Siswa pada Siklus I dan Siklus II

\begin{tabular}{|c|l|c|c|}
\hline No & $\begin{array}{c}\text { Aspek } \\
\text { Penilaian }\end{array}$ & $\begin{array}{c}\text { Siklus } \\
\text { I }\end{array}$ & $\begin{array}{c}\text { Siklus } \\
\text { II }\end{array}$ \\
\hline 1 & Afektif & 56,58 & 77,21 \\
\hline 2 & Kognitif & 54,17 & 95,83 \\
\hline 3 & Psikomotorik & 63,67 & 78,04 \\
\hline
\end{tabular}

Dalam bentuk diagram batang sebagaimaana penjelasan pada gambar dibawah ini :

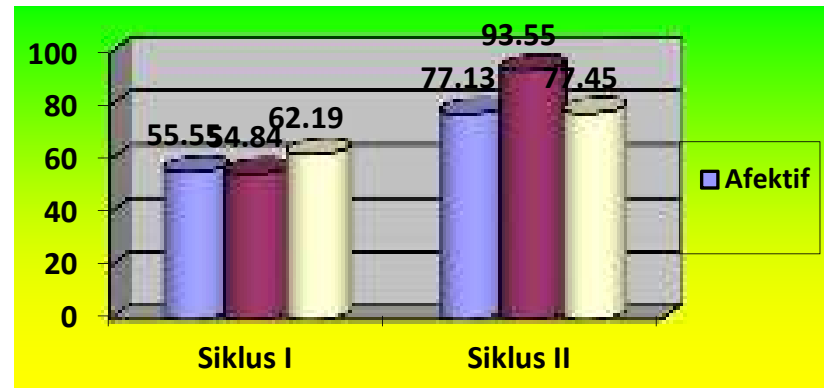

Gambar 4. Peningkatan Keterampilan Afektf, Kognitif dan Psikomotorik Siswa pada Siswa pada Siklus I dan Siklus II

Dalam melakukan penelitian masih terdapat berbagai kelemahan dan kekurangan, walaupun peneliti telah berupaya semaksimal mungkin dengan berbagai usaha untuk membuat hasil penelitian ini bisa menjadi sempurna. Peneliti menyadari bahwa keterbatasan penelitian ini antara lain sebagai berikut.

Pertama, penelitian ini hanya membahas aspek-aspek kemampuan bola voli mini, yaitu aspek afektif, kognitif dan psikomotor. Sedangkan secara objektif masih banyak faktor lain yang mendukung peningkatan prestasi bola boli mini yang tidak dicakup dalam penelitian Kedua, walaupun peneliti sebelum melakukan penelitian telah melakukan serangkaian uji coba untuk mendapatkan instrumen yang valid dan reliabel, namun demikian pengumpulan melalui angket ini masih ada kelemahan-kelemahan seperti jawaban yang kurang cermat, responden yang menjawab asal-asalan dan tidak jujur, serta pertanyaan yang kurang lengkap. Ketiga, sebagai pribadi peneliti mempunyai keterbatasan dalam melakukan penelaahan penelitian, pengetahuan yang kurang, literatur yang kurang, waktu dan tenaga. Hal ini merupakan kendala bagi peneliti untuk melakukan penyusunan yang mendekati sempurna. Keempat, terlepas dari adanya kekurangan namun hasil penelitian ini telah memberikan informasi yang sangat penting bagi perkembangan guru yaitu modifikasi permainan Bolavoli mini dapat diterima oleh siswa dan dapat diterapkan di Sekolah. 
KESIMPULAN

Pembelajaran Penjasorkes dengan modifikasi permainan Bolavoli mini dapat diterima oleh siswa dan dapat diterapkan di SMPN 3 Bukit Kabupaten Bener Meriah. Permainan ini dapat mencakup semua aspek baik afektif, kognitif, dan psikomotor.

1. Hasil akhir pengamatan perilaku siswa (afektif) dengan pencapaian sebesar $77,21 \%$ yang masuk ke dalam kriteria baik.

2. Hasil akhirpengamatan pemahaman siswa (kognitif) dengan pencapaian sebesar $95,83 \%$ yang masuk ke dalam kriteria sangat baik.

3. Hasil akhir pengamatan keterampilan siswa (psikomotor) dengan pencapaian sebesar $78,04 \%$ yang masuk ke dalam kriteria baik.

\section{DAFTAR PUSTAKA}

A Husna M. 2009. 100+Permainan Tradisional Indonesia. Yogyakarta : C.V Andi Offset.

Adang Suherman. 2000. Dasar-dasar Penjaskes. Jakarta : Depdikbud.

Among Ma"mun dan Yudha Saputra. 2000. Perkembangan gerak dan Belajar Gerak. Jakarta : Depdiknas.

Ateng, Abdul Kadir. 1992. Asas dan Landasan Pendidikan Jasmani. Jakarta :
Depdikbud.

Mulyasa. 2010. Menjadi Guru Profesional. Bandung : PT Remaja Rosdakarya.

Oktia Woro Kasimi. 1999. Praktikum dan ketrampilan pendidikan kesehatan. Semarang : Fakultas Ilmu Keolahragaan UnVIersitas Negeri Semarang.

Soemitro. 1992. Permainan Kecil. Jakarta : Depdikbud.

Suharsini Arikunto. 2006. Prosedur Penelitian. Jakarta : Rineka Cipta.

Suherman, dan Bahagia. 2000. Prinsipprinsip Pengembangan dan Modifikasi Cabang Olahraga. Jakarta : Depdiknas.

Sukintaka. 1992. Teori Bermain. Jakarta : Depdikbud.

Tim Penyusun. 2009. Panduan Penyusunan Skripsi. Semarang : Fakultas Ilmu Keolahragaan UnVIersitas Negeri Semarang.

Trianto. 2010. Model Pembelajaran Terpadu. Jakarta : PT Bumi Aksara.

Usman Uzer. 2010. Menjadi Guru Profesional. Bandung : PT Remaja Rosdakarya.

Lutan, Rusli. dan Suherman, Adang. (2000). Perencanaan Pembelajaran Penjas. Depdiknas. Jakarta. 